\title{
Analiza skuteczności działania dodatków smarnych na podstawie badań przeprowadzonych z użyciem symulatora wiercenia Grace M2200
}

\begin{abstract}
Artykuł przedstawia analizę skuteczności działania nowoczesnych środków smarnych w inhibitowanych płuczkach wiertniczych opartą na zachodzących zmianach wartości współczynnika tarcia przy zadawanej różnej koncentracji danego środka. W toku realizacji badań sprawdzono działanie czterech środków smarnych. Dodawane były one w koncentracji $0,5 \%, 1,0 \%$ oraz 1,5\% do dwóch rodzajów płuczek wiertniczych: polimerowo-potasowej oraz glikolowo-potasowej. Badania skuteczności działania prowadzono poprzez pomiar współczynnika tarcia za pomocą aparatu Grace M2200 HPHT. Współczynnik tarcia określany był dla kontaktów stal-stal, stal-piaskowiec. Ponadto określono wpływ badanych środków na podstawowe parametry oraz właściwości inhibitacyjne płuczek wiertniczych.
\end{abstract}

Słowa kluczowe: środki smarne, smarność, współczynnik tarcia, płuczka wiertnicza.

\section{Analysis of lubricity additives effectiveness based on research performed with the Grace M2200 drilling simulator}

\begin{abstract}
The article presents an analysis of modern lubricity additives effectiveness in inhibited drilling fluids, based on the coefficient of friction value changes. Four lubricity additives were tested throughout the studies. They were added at concentrations of $0.5 \%, 1.0 \%$ and $1.5 \%$ for the two types of drilling fluids: polymer-potassium and glycol-potassium muds. The studies were conducted based on the measurement of the coefficient of friction using a Grace M2200 HPHT drilling simulator. The coefficient of friction was determined on steel-steel contact and steel-sandstone contact. In addition, the impact of the examined agents on the rheological parameters and inhibitive properties of drilling muds was determined.
\end{abstract}

Key words: lubricity additives, lubricity, friction coefficient, drilling mud.

\section{Wstęp}

W związku z dużym zainteresowaniem wydobyciem gazu ziemnego ze złóż zarówno konwencjonalnych, jak i niekonwencjonalnych przewiduje się, że w najbliższej przyszłości zostanie wykonana znaczna liczba odwiertów poszukiwawczych, a następnie wydobywczych. Będą to często otwory głębokie, $\mathrm{w}$ tym również kierunkowe, $\mathrm{w}$ których procesie wiercenia bardzo dużą rolę odgrywają właściwości smarne płuczek wiertniczych $[19,22]$. Występujące podczas wiercenia tarcie pomiędzy przewodem wiertniczym a ścianą otworu, świdrem a zwiercaną skałą oraz gryzem świdra a jego osią powoduje wzrost: oporów hydraulicznych w czasie zapuszczania i wyciągania przewodu, momentu obrotowego oraz cieplnego i zmęczeniowego zużycia narzędzi wiertniczych. Stosowanie odpowiednich środków smarnych, dzięki którym możliwe staje się utrzymywanie jak najniższego współczynnika tarcia, skutkuje polepszeniem zwiercalności skał, zmniejszeniem oporów hydraulicznych przepływu płuczki oraz momentu skręcającego przewód wiertniczy [7]. Ponadto zmniejszeniu ulega zużycie wykorzystywanych narzędzi wiertniczych. W związku z tym, że w otworach głębokich panują warunki wysokiego ciśnienia oraz wysokiej temperatury, przeprowadzona została analiza skuteczności działania nowoczesnych środków smarnych w stosowanych obecnie inhibitowanych płuczkach wiertniczych w warunkach HPHT. 


\section{Środki smarne w technologii płuczkowej}

Środki smarne dodawane są do płuczek wiertniczych przede wszystkim w celu zminimalizowania siły tarcia występującej na stykających się powierzchniach $[11,16]$. Siłę tarcia określa się zależnością:

$$
T=\mu \cdot F_{n}
$$

gdzie:

$\mu$ - współczynnik tarcia,

$F_{n}-$ siła nacisku obiektu na podłoże $[5,18,20]$.

Wysoka smarność płuczki wiertniczej może zwiększyć szybkość zwiercania formacji skalnej, co prowadzi do znacznych oszczędności kosztów wiercenia otworu. Niedostateczne właściwości smarne płuczki mogą z kolei prowadzić do szeregu problemów, takich jak zwiększone zużycie łożysk świdra, zużywanie kolumn rur okładzinowych, wzrost momentu obrotowego czy przyklejanie przewodu wiertniczego $[1,3,11]$. To właśnie niska smarność płuczki wiertniczej uważana jest za jeden z ważniejszych, po zbyt dużej różnicy pomiędzy ciśnieniem hydrostatycznym a ciśnieniem formacji, powodów przyklejania się przewodu wiertniczego do osadu filtracyjnego pokrywającego ścianę otworu.

Dodatki smarne powinny charakteryzować następujące właściwości:

- wysoka lepkość,

- wysoka wytrzymałość filmu smarującego,

- niska korozyjność,

- niska temperatura krzepnięcia,

- niska palność,

- wysoka stabilność termiczna,

- niska toksyczność [11].

Środki smarne stosowane są głównie w płuczkach wodnodyspersyjnych, ponieważ właściwości smarne tych systemów, w przeciwieństwie do płuczek olejowodyspersyjnych, są niewystarczające. Mimo że płuczki olejowe naturalnie wykazują wysoką smarność, to jednak w większości przypadków stosuje się płuczki wodnodyspersyjne, głównie z uwagi na ich stosunkowo niski koszt, niską toksyczność i biodegradowalność [4, 20].

Ponieważ odpowiednie właściwości smarne płuczki odgrywają tak dużą rolę w prawidłowym procesie wiercenia, prowadzone są szerokie badania nad opracowaniem nowych rodzajów środków smarnych. Literatura podaje takie środki jak:

- mieszaniny estrów olejów roślinnych, emulgatorów niejonowych oraz olejów mineralnych [6],

- biolubrykanty tworzone na bazie olejów pochodzenia roślinnego, takich jak: olej rycynowy, kokosowy, talowy, sojowy, słonecznikowy czy rzepakowy [2, 8],

- węglowe nanorurki, nanokrzemionka, szklane kulki $[10,17]$,

- środki fosfolipidowe PLC [9],

- nienasycone kwasy thuszczowe oraz ich mieszaniny, mydła, etery i inne [20].

Uwzględniając występowanie różnych warunków złożowych, środki smarne stosowane w technologii płuczek wiertniczych można podzielić na [14, 18, 20,21]:

- środki zmniejszające tarcie przy małych naciskach, których zadaniem jest obniżenie tarcia przewodu wiertniczego o ścianę otworu wiertniczego w miejscach, gdzie wielkość nacisku nie przekracza $35 \mathrm{MPa}$,

- środki przeciwzatarciowe zmniejszające tarcie przy ekstremalnie wysokich naciskach, zwane środkami EP, których zadaniem jest obniżenie tarcia i ochrona powierzchni metalu przed ścieraniem przy naciskach $35 \div 700 \mathrm{MPa}$,

- środki pośredniczące w przenoszeniu nacisku - najczęściej są to ciała stałe, np. drobne kuleczki szklane lub plastikowe (środki twarde) oraz materiały włókniste pochodzenia organicznego (miękkie).

\section{Zakres badań}

W pierwszym etapie badań wytypowane zostały cztery środki o właściwościach smarnych: SL, EL6, B5000, B5400. Kolejnym krokiem był dobór płuczek wiertniczych stosowanych obecnie do głębokich wierceń w warunkach HPHT, które miały być modyfikowane przez dodatek środków smarnych. Wybrano płuczki o podwójnym inhibitowaniu polimerowo-jonowym: płuczkę polimerowo-potasową oraz płuczkę glikolowo-potasową. Obydwa rodzaje płuczek wykorzystanych w badaniach laboratoryjnych opierały się na tym samym zestawie polimerów strukturotwórczych, którymi były: PAC LV, PAC R, XCD oraz Rotomag. Podobnie w obydwu rodzajach płuczek jednym z zastosowanych inhibitorów hydratacji łupków był chlorek potasu, który pełnił rolę jonowego inhibitora hydratacji skał ilastych. W płuczce glikolowo-potasowej rolę inhibitora polimerowego pełni dwuskładnikowy układ blokowego kopolimeru tlenku etylenu i tlenku propylenu w połączeniu z oksyetylenowanym trójglicerydem kwasu rycynolowego. W przypadku płuczki polimerowo-potasowej funkcję inhibitora polimerowego spełnia częściowo hydrolizowany poliakryloamid (PHPA).

W kolejnym etapie mierzono współczynnik tarcia w płuczkach wyjściowych oraz w płuczkach z dodatkiem poszczególnych 
środków smarnych w stężeniu 0,5\%, 1,0\% i 1,5\%. Badania przeprowadzano na dwóch materiałach: stali i piaskowcu. Dzięki temu można było ocenić efektywność działania testowanych środków nie tylko na kontakcie stal-stal, jak to miało miejsce dotychczas przy użyciu aparatu EP-Tester, ale również na kontakcie stal-piaskowiec. Pomiary wykonywano w temperaturze $20^{\circ} \mathrm{C}$ oraz w warunkach zbliżonych do panujących w głębokich otworach, czyli w temperaturze $80^{\circ} \mathrm{C}$. Badanie współczynnika tarcia na kontakcie stal-stal odbywało się przy czterech poziomach nacisku: 133, 289, 445 oraz 578 niutonów (30, 65, 100 oraz 130 funtów). W przypadku piaskowca nie prowadzono pomiarów przy nacisku 578 niutonów, ponieważ takie obciążenie powodowało kruszenie się próbek. Dla każdego poziomu nacisku wykonywano pięć pomiarów przy różnych prędkościach obrotowych rotora: 10, 20, 30, 40 i $50 \mathrm{obr} / \mathrm{min}$. Każde badanie współczynnika tarcia na kontakcie stal-stal składało się zatem z dwudziestu odczytów dokonywanych przy różnych konfiguracjach nacisk-prędkość obrotowa, natomiast badania współczynnika tarcia na styku stal-piaskowiec składały się z piętnastu odczytów. Tak zaplanowane prace pozwalały sporządzić wykresy obrazujące zależność współczynnika tarcia od nacisku i prędkości obrotowej rotora przy różnych koncentracjach środków smarnych w płuczkach. Przyjęto, że przy porównywaniu skuteczności działania poszczególnych środków smarnych brany będzie pod uwagę odczyt współczynnika tarcia wykonany przy nacisku 100 funtów (445 N) i prędkości obrotowej 50 obr/min. Takie założenie wynika $\mathrm{z}$ faktu, że są to warunki najbardziej zbliżone do tych, przy jakich norma nakazuje wykonywać pomiary za pomocą urządzenia EP-Tester.

W kolejnym etapie określono wpływ badanych środków smarnych na podstawowe parametry technologiczne pluczek, takie jak właściwości reologiczne, ciężar właściwy, filtracja, $\mathrm{pH}$, oraz na ich właściwości inhibitacyjne.

\section{Pomiar współczynnika tarcia}

Do pomiaru współczynnika tarcia wykorzystano unikatowy na skalę światową aparat Grace M2200 HPHT. Umożliwia on przeprowadzenie pomiaru smarności i filtracji dynamicznej płuczek wiertniczych w symulowanych warunkach otworowych. Dodatkową funkcją jest pomiar szybkości wiercenia w rzeczywistych próbkach skał za pomocą miniaturowego świdra wiertniczego. Aparat umożliwia realistyczne symulowanie warunków otworowych dzięki dużemu zakresowi temperatury roboczej (do $260^{\circ} \mathrm{C}$ ) oraz ciśnienia (do 13,8 MPa). Obsługa odbywa się przy użyciu nowoczesnego oprogramowania komputerowego M2200 PC.

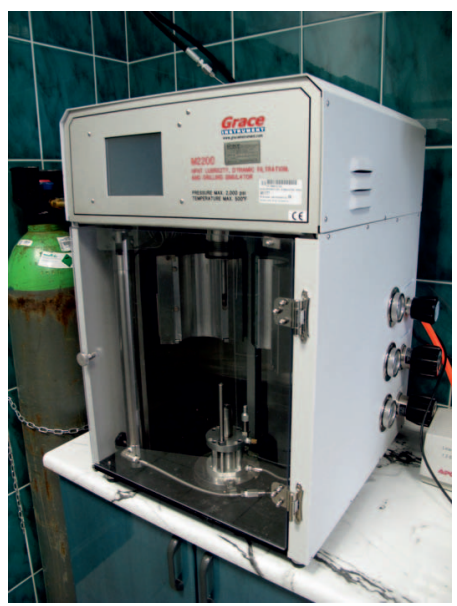

Fot. 1. Aparat Grace M2200 HPHT

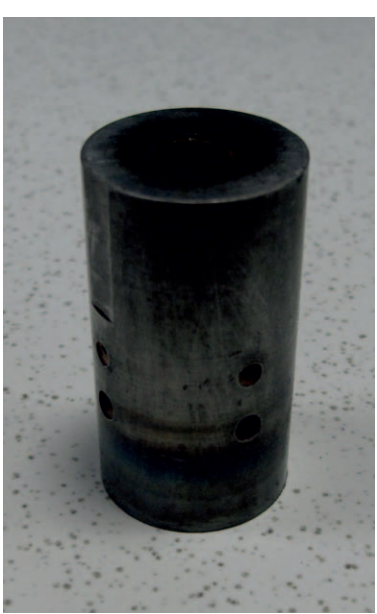

Fot. 2. Rotor
Podczas pomiaru współczynnika tarcia obracający się z zadaną prędkością stalowy rotor jest dociskany do metalowego walca (w przypadku pomiaru na kontakcie metal-metal) bądź do próbki skały (pomiar na kontakcie stal-skała). Całość zanurzona jest w badanej płuczce wiertniczej. Aparat mierzy moment obrotowy potrzebny do obracania rotora z zadaną prędkością przy zadanym docisku do próbki. Na podstawie tego pomiaru obliczana jest smarność badanej płuczki.

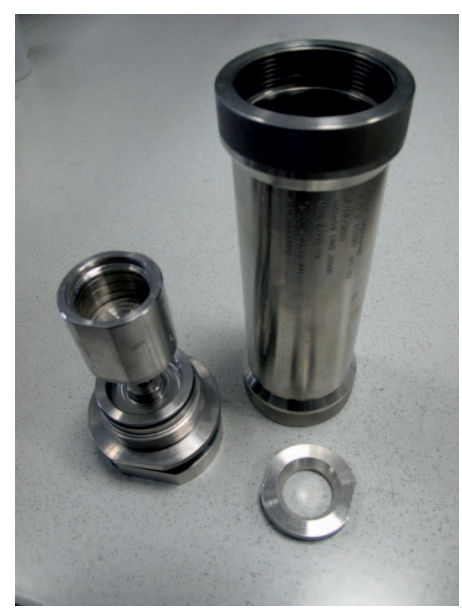

Fot. 3. Uchwyt na próbkę i komora

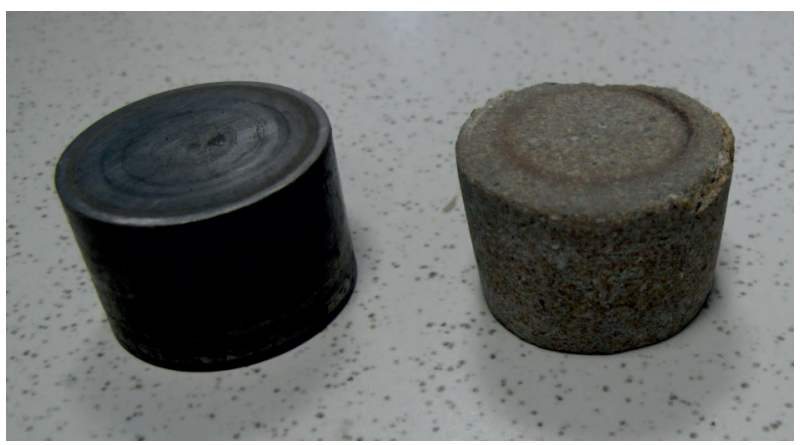

Fot. 4. Próbki wykorzystane podczas badań: stal i piaskowiec 
Pomiar współczynnika tarcia rozpoczynał się od umieszczenia stalowego walca bądź rdzenia wyciętego z piaskowca w uchwycie. Próbkę w uchwycie zabezpieczano poprzez dokręcenie stalowego pierścienia, uniemożliwiającego jej przesunięcie lub obrót. Następnie uchwyt z zamocowaną prób- ką wkręcano do komory, do której nalewano $325 \mathrm{~cm}^{3}$ badanej płuczki. Całość przykręcano do gniazda aparatu, gdzie na wale obrotowym zamocowany był rotor. Kolejny krok stanowiło przygotowanie odpowiedniej sekwencji pomiarowej w programie M2200 PC.

\section{Wyniki pomiaru współczynnika tarcia}

W tablicy 1 oraz na rysunkach 1 i 2 przedstawiono wyniki pomiarów współczynnika tarcia w płuczce polimerowo-potasowej wyjściowej oraz obrobionej przez dodatek środków smarnych w stężeniach od $0,5 \%$ do $1,5 \%$. W temperaturze $20^{\circ} \mathrm{C}$ na kontakcie stal-stal współczynnik tarcia miał wartość 0,28 i ulegał stopniowemu obniżeniu wraz z rosnącą koncentracją środków smarnych w płuczce. Przy stężeniu 1,5\% środka SL współczynnik tarcia osiągnął wartość 0,18 . Zbliżony wynik odnotowano w temperaturze $80^{\circ} \mathrm{C}$. Z kolei pomiary wykonane na kontakcie stal-piaskowiec wykazały bardzo szybkie obniżenie wartości współczynnika tarcia już przy stężeniu środka SL wynoszącym $0,5 \%$. Taka tendencja widoczna była zarówno w temperaturze $20^{\circ} \mathrm{C}$, jak i $80^{\circ} \mathrm{C}$.

Po zmodyfikowaniu płuczki dodatkiem EL6 zauważyć można, że na kontakcie stal-stal już przy stężeniu $0,5 \%$ nastąpiło wyraźne obniżenie wartości współczynnika tarcia. Wynosiła ona odpowiednio 0,16 i 0,20 dla temperatury $20^{\circ} \mathrm{C}$ i $80^{\circ} \mathrm{C}$. Przy koncentracji środka smarnego równej $1,5 \%$ było to 0,11 oraz 0,17 . Na kontakcie stal-piaskowiec ponownie nastąpiło znaczne zmniejszenie się współczynnika tarcia już przy stężeniu EL6 wynoszącym 0,5\%.
Kolejnym środkiem, którego wpływ na właściwości smarne płuczek badano, był B5000. Stężenie $0,5 \%$ powodowało obniżenie współczynnika tarcia na kontakcie stal-stal w temperaturze $20^{\circ} \mathrm{C} \mathrm{z} 0,28$ do 0,18 . Przy stężeniu $1,5 \%$ współczynnik tarcia miał wartość 0,15 . Podobnie jak w przypadku środków SL i EL6 następowało bardzo szybkie zmniejszanie się współczynnika tarcia na kontakcie stali z piaskowcem. Już przy zawartości środka w płuczce wynoszącej 0,5\% wartość współczynnika tarcia osiągnęła $0,15 \mathrm{w}$ temperaturze $20^{\circ} \mathrm{C}$ oraz $0,13 \mathrm{w}$ temperaturze $80^{\circ} \mathrm{C}$. W przypadku stężenia $1,5 \%$ było to już tylko 0,12 i 0,10 .

Środek B5400 wykazał się najniższą efektywnością w obniżaniu współczynnika tarcia. W temperaturze $20^{\circ} \mathrm{C}$ na kontakcie stal-stal współczynnik tarcia był równy 0,20 przy koncentracji środka równej $1,5 \%$. Podobne rezultaty osiągnięto $\mathrm{w}$ temperaturze $80^{\circ} \mathrm{C}$. Również w przypadku badań przeprowadzonych na próbce piaskowca wyniki były gorsze niż te uzyskane przez pozostałe środki smarne.

W tablicy 2 oraz na rysunkach 3 i 4 zamieszczono wyniki pomiarów współczynnika tarcia w płuczce glikolowo-potasowej wyjściowej oraz obrobionej za pomocą środków smarnych.

Tablica 1. Zestawienie wartości współczynnika tarcia dla różnych materiałów przy zastosowaniu płuczki polimerowo-potasowej oraz jej modyfikacji środkami smarnymi w różnych stężeniach

\begin{tabular}{|c|c|c|c|c|c|c|c|c|c|}
\hline \multirow{3}{*}{ Rodzaj płuczki } & \multirow{3}{*}{$\begin{array}{c}\text { Stężenie } \\
\text { środka } \\
\text { smarnego }\end{array}$} & \multicolumn{8}{|c|}{ Materiały kontaktowe } \\
\hline & & \multicolumn{4}{|c|}{ stal-stal } & \multicolumn{4}{|c|}{ stal-piaskowiec } \\
\hline & & \multicolumn{2}{|c|}{$20^{\circ} \mathrm{C}$} & \multicolumn{2}{|c|}{$80^{\circ} \mathrm{C}$} & \multicolumn{2}{|c|}{$20^{\circ} \mathrm{C}$} & \multicolumn{2}{|c|}{$80^{\circ} \mathrm{C}$} \\
\hline $\begin{array}{l}\text { Wyjściowa płuczka } \\
\text { polimerowo-potasowa }\end{array}$ & - & \multicolumn{2}{|c|}{0,28} & \multicolumn{2}{|c|}{0,28} & \multicolumn{2}{|c|}{0,45} & \multicolumn{2}{|c|}{0,34} \\
\hline \multirow{3}{*}{$\begin{array}{l}\text { Płuczka polimerowo- } \\
\text { potasowa }+ \text { SL }\end{array}$} & $0,5 \%$ & 0,23 & $\downarrow 18 \%$ & 0,20 & $\downarrow 29 \%$ & 0,17 & $\downarrow 62 \%$ & 0,12 & $\downarrow 65 \%$ \\
\hline & $1,0 \%$ & 0,21 & $\downarrow 25 \%$ & 0,20 & $\downarrow 29 \%$ & 0,12 & $\downarrow 73 \%$ & 0,11 & $\downarrow 68 \%$ \\
\hline & $1,5 \%$ & 0,18 & $\downarrow 36 \%$ & 0,19 & $\downarrow 32 \%$ & 0,12 & $\downarrow 73 \%$ & 0,10 & $\downarrow 71 \%$ \\
\hline \multirow{3}{*}{$\begin{array}{l}\text { Płuczka polimerowo- } \\
\text { potasowa + EL6 }\end{array}$} & $0,5 \%$ & 0,16 & $\downarrow 43 \%$ & 0,20 & $\downarrow 29 \%$ & 0,13 & $\downarrow 71 \%$ & 0,12 & $\downarrow 65 \%$ \\
\hline & $1,0 \%$ & 0,12 & $\downarrow 57 \%$ & 0,17 & $\downarrow 39 \%$ & 0,12 & $\downarrow 73 \%$ & 0,10 & $\downarrow 71 \%$ \\
\hline & $1,5 \%$ & 0,11 & $\downarrow 61 \%$ & 0,17 & $\downarrow 39 \%$ & 0,12 & $\downarrow 73 \%$ & 0,11 & $\downarrow 68 \%$ \\
\hline \multirow{3}{*}{$\begin{array}{l}\text { Płuczka polimerowo- } \\
\text { potasowa }+\mathbf{B 5 0 0 0}\end{array}$} & $0,5 \%$ & 0,18 & $\downarrow 36 \%$ & 0,19 & $\downarrow 32 \%$ & 0,15 & $\downarrow 67 \%$ & 0,13 & $\downarrow 62 \%$ \\
\hline & $1,0 \%$ & 0,17 & $\downarrow 39 \%$ & 0,19 & $\downarrow 32 \%$ & 0,12 & $\downarrow 73 \%$ & 0,10 & $\downarrow 71 \%$ \\
\hline & $1,5 \%$ & 0,15 & $\downarrow 46 \%$ & 0,18 & $\downarrow 36 \%$ & 0,12 & $\downarrow 73 \%$ & 0,10 & $\downarrow 71 \%$ \\
\hline \multirow{3}{*}{$\begin{array}{l}\text { Płuczka polimerowo- } \\
\text { potasowa }+\mathbf{B 5 4 0 0}\end{array}$} & $0,5 \%$ & 0,24 & $\downarrow 14 \%$ & 0,30 & $\uparrow 7 \%$ & 0,20 & $\downarrow 56 \%$ & 0,16 & $\downarrow 53 \%$ \\
\hline & $1,0 \%$ & 0,21 & $\downarrow 25 \%$ & 0,25 & $\downarrow 11 \%$ & 0,17 & $\downarrow 62 \%$ & 0,15 & $\downarrow 56 \%$ \\
\hline & $1,5 \%$ & 0,20 & $\downarrow 29 \%$ & 0,24 & $\downarrow 14 \%$ & 0,14 & $\downarrow 69 \%$ & 0,13 & $\downarrow 62 \%$ \\
\hline
\end{tabular}




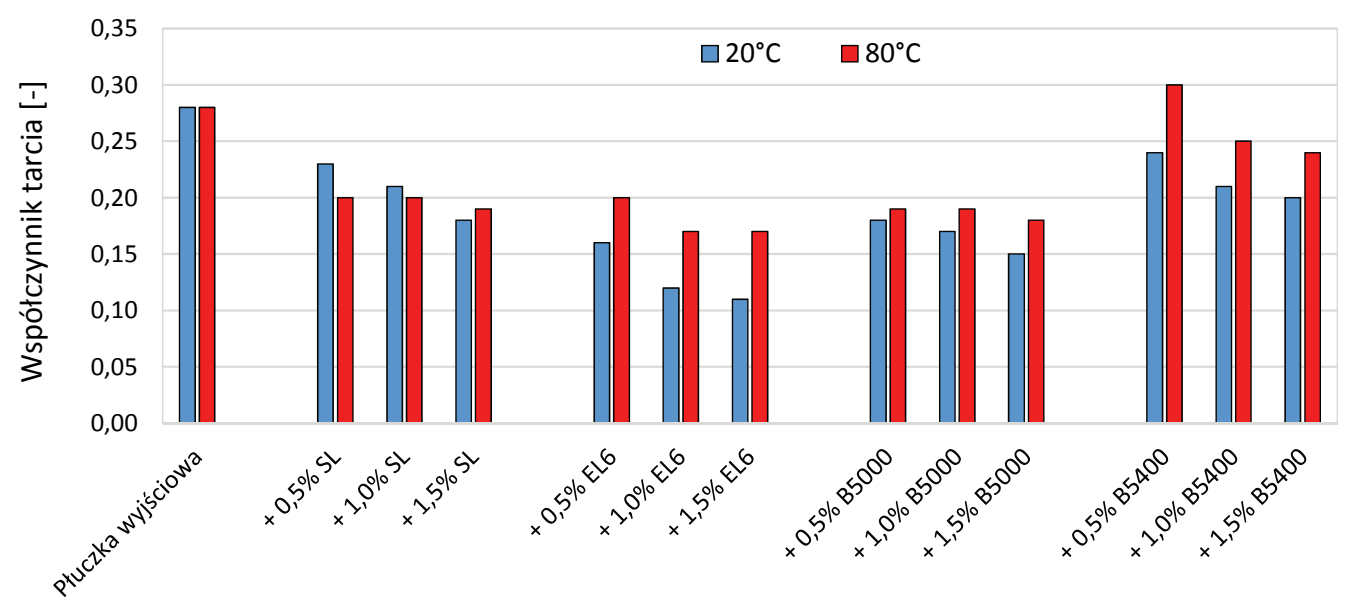

Rys. 1. Współczynnik tarcia na kontakcie stal-stal w płuczce polimerowo-potasowej przy różnych stężeniach środków smarnych

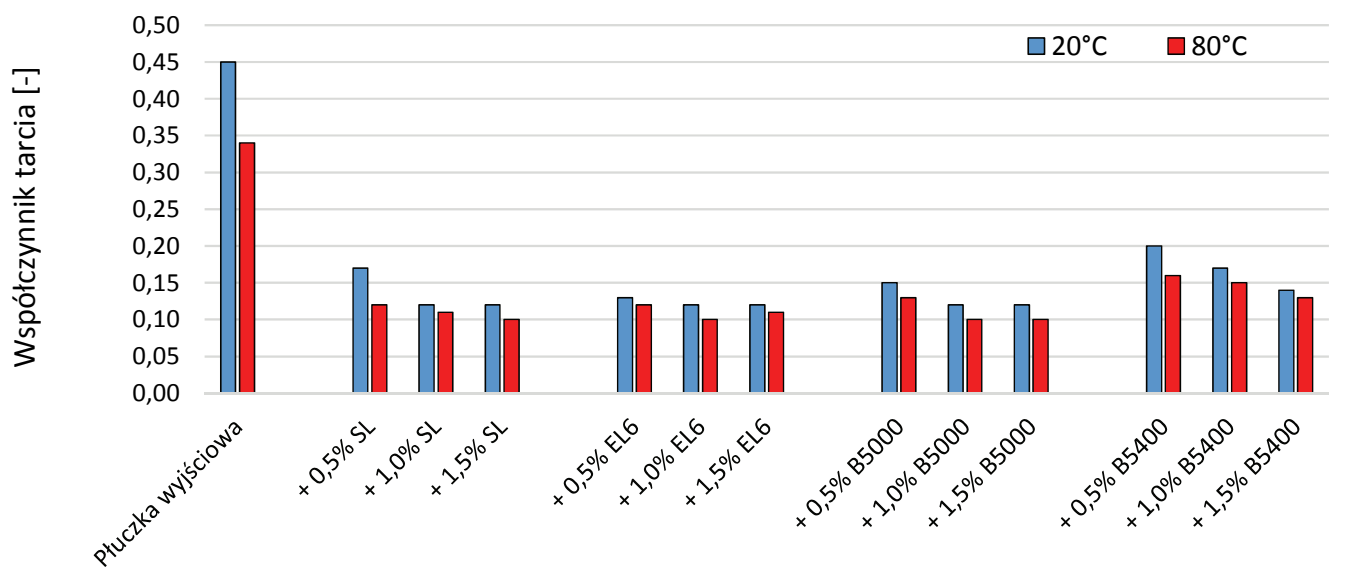

Rys. 2. Współczynnik tarcia na kontakcie stal-piaskowiec w płuczce polimerowo-potasowej przy różnych stężeniach środków smarnych

Dodanie środka SL w stężeniu 0,5\% spowodowało obniżenie współczynnika tarcia na kontakcie stal-stal z 0,28 do 0,19. Przy stężeniu $1,5 \%$ współczynnik tarcia miał wartość 0,16 . Bardzo szybko nastąpiło obniżanie współczynnika tarcia na kontakcie stali z piaskowcem - przy stężeniu środka w płuczce wynoszącym $0,5 \%$ wartość współczynnika była równa $0,16 \mathrm{w}$ temperaturze $20^{\circ} \mathrm{C}$ oraz $0,14 \mathrm{w}$ temperaturze $80^{\circ} \mathrm{C}$. W przypadku stężenia $1,5 \%$ wartości wynosiły odpowiednio 0,12 i 0,11 .

Zmodyfikowanie płuczki poprzez dodanie środka EL6 skutkowało stopniowym zmniejszaniem się współczynnika tarcia wraz z rosnącą koncentracją środka smarnego w płuczce. Przy stężeniu 1,5\% środka współczynnik tarcia miał wartość 0,11 na kontakcie stal-stal. Pomiary wykonane na kontakcie stal-piaskowiec wykazały bardzo szybkie obniżenie wartości współczynnika tarcia już przy stężeniu środka EL6 wynoszącym $0,5 \%$. Taka tendencja widoczna była zarówno w temperaturze $20^{\circ} \mathrm{C}$, jak i $80^{\circ} \mathrm{C}$.

Stężenie środka B5000 równe $0,5 \%$ powodowało obniżenie współczynnika tarcia na kontakcie stal-stal z 0,28 do 0,24 . Przy stężeniu 1,5\% współczynnik tarcia miał wartość 0,16 . Podobnie jak w przypadku innych środków bardzo szybko nastąpiło zmniejszanie się współczynnika tarcia na kontakcie stali ze skałą. Przy stężeniu środka w płuczce wynoszącym $0,5 \%$ - wartości współczynnika tarcia wynosify $0,16 \mathrm{w}$ temperaturze $20^{\circ} \mathrm{C}$ oraz $0,13 \mathrm{w}$ temperaturze $80^{\circ} \mathrm{C}$. W przypadku stężenia $1,5 \%$ było to odpowiednio 0,13 i 0,12 .

Podobnie jak w badaniach płuczki polimerowo-potasowej efektywność oddziaływania środka B5400 była najniższa. W temperaturze $20^{\circ} \mathrm{C}$ na kontakcie stal-stal współczynnik tarcia miał wartość 0,17 przy koncentracji środka równej 1,5\%, natomiast w temperaturze $80^{\circ} \mathrm{C}$ wynosił 0,20 . Podobne rezultaty otrzymano w temperaturze $80^{\circ} \mathrm{C}$. Również w przypadku badań przeprowadzonych na próbkach piaskowca uzyskano wyniki gorsze niż te osiągnięte przez pozostałe środki smarne.

Niepewność uzyskanych wyników pomiarów współczynnika tarcia zaprezentowanych $\mathrm{w}$ tablicach 1-2 oznaczono na podstawie klasy dokładności aparatu Grace M200 na poziomie $0,5 \%$, natomiast niepewność wyników pomiarów dyspersji łupku mioceńskiego (tablice 3-4) oszacowano na poziomie $2 \%$. 
Tablica 2. Zestawienie wartości współczynnika tarcia dla różnych materiałów przy zastosowaniu płuczki glikolowo-potasowej oraz jej modyfikacji środkami smarnymi w różnych stężeniach

\begin{tabular}{|c|c|c|c|c|c|c|c|c|c|}
\hline \multirow{3}{*}{ Rodzaj płuczki } & \multirow{3}{*}{$\begin{array}{c}\text { Stężenie } \\
\text { środka } \\
\text { smarnego }\end{array}$} & \multicolumn{8}{|c|}{ Materiały kontaktowe } \\
\hline & & \multicolumn{4}{|c|}{ stal-stal } & \multicolumn{4}{|c|}{ stal-piaskowiec } \\
\hline & & \multicolumn{2}{|c|}{$20^{\circ} \mathrm{C}$} & \multicolumn{2}{|c|}{$80^{\circ} \mathrm{C}$} & \multicolumn{2}{|c|}{$20^{\circ} \mathrm{C}$} & \multicolumn{2}{|c|}{$80^{\circ} \mathrm{C}$} \\
\hline $\begin{array}{l}\text { Wyjściowa płuczka } \\
\text { glikolowo-potasowa }\end{array}$ & - & \multicolumn{2}{|c|}{0,28} & \multicolumn{2}{|c|}{0,23} & \multicolumn{2}{|c|}{0,29} & \multicolumn{2}{|c|}{0,31} \\
\hline \multirow{3}{*}{$\begin{array}{l}\text { Płuczka glikolowo- } \\
\text { potasowa + SL }\end{array}$} & $0,5 \%$ & 0,19 & $\downarrow 32 \%$ & 0,21 & $\downarrow 9 \%$ & 0,16 & $\downarrow 45 \%$ & 0,14 & $\downarrow 55 \%$ \\
\hline & $1,0 \%$ & 0,17 & $\downarrow 39 \%$ & 0,18 & $\downarrow 22 \%$ & 0,13 & $\downarrow 55 \%$ & 0,11 & $\downarrow 65 \%$ \\
\hline & $1,5 \%$ & 0,16 & $\downarrow 43 \%$ & 0,17 & $\downarrow 26 \%$ & 0,12 & $\downarrow 59 \%$ & 0,11 & $\downarrow 65 \%$ \\
\hline \multirow{3}{*}{$\begin{array}{l}\text { Płuczka glikolowo- } \\
\text { potasowa + EL6 }\end{array}$} & $0,5 \%$ & 0,14 & $\downarrow 50 \%$ & 0,18 & $\downarrow 22 \%$ & 0,12 & $\downarrow 59 \%$ & 0,11 & $\downarrow 65 \%$ \\
\hline & $1,0 \%$ & 0,12 & $\downarrow 57 \%$ & 0,16 & $\downarrow 30 \%$ & 0,11 & $\downarrow 62 \%$ & 0,10 & $\downarrow 68 \%$ \\
\hline & $1,5 \%$ & 0,10 & $\downarrow 64 \%$ & 0,15 & $\downarrow 35 \%$ & 0,11 & $\downarrow 62 \%$ & 0,10 & $\downarrow 68 \%$ \\
\hline \multirow{3}{*}{$\begin{array}{l}\text { Płuczka glikolowo- } \\
\text { potasowa + B5000 }\end{array}$} & $0,5 \%$ & 0,24 & $\downarrow 14 \%$ & 0,25 & $\uparrow 9 \%$ & 0,16 & $\downarrow 45 \%$ & 0,13 & $\downarrow 58 \%$ \\
\hline & $1,0 \%$ & 0,18 & $\downarrow 36 \%$ & 0,18 & $\downarrow 22 \%$ & 0,14 & $\downarrow 52 \%$ & 0,12 & $\downarrow 61 \%$ \\
\hline & $1,5 \%$ & 0,16 & $\downarrow 43 \%$ & 0,17 & $\downarrow 26 \%$ & 0,13 & $\downarrow 55 \%$ & 0,12 & $\downarrow 61 \%$ \\
\hline \multirow{3}{*}{$\begin{array}{l}\text { Płuczka glikolowo- } \\
\text { potasowa + B5400 }\end{array}$} & $0,5 \%$ & 0,21 & $\downarrow 25 \%$ & 0,23 & $0 \%$ & 0,18 & $\downarrow 38 \%$ & 0,15 & $\downarrow 52 \%$ \\
\hline & $1,0 \%$ & 0,19 & $\downarrow 32 \%$ & 0,19 & $\downarrow 17 \%$ & 0,16 & $\downarrow 45 \%$ & 0,14 & $\downarrow 55 \%$ \\
\hline & $1,5 \%$ & 0,17 & $\downarrow 39 \%$ & 0,20 & $\downarrow 13 \%$ & 0,15 & $\downarrow 48 \%$ & 0,13 & $\downarrow 58 \%$ \\
\hline
\end{tabular}

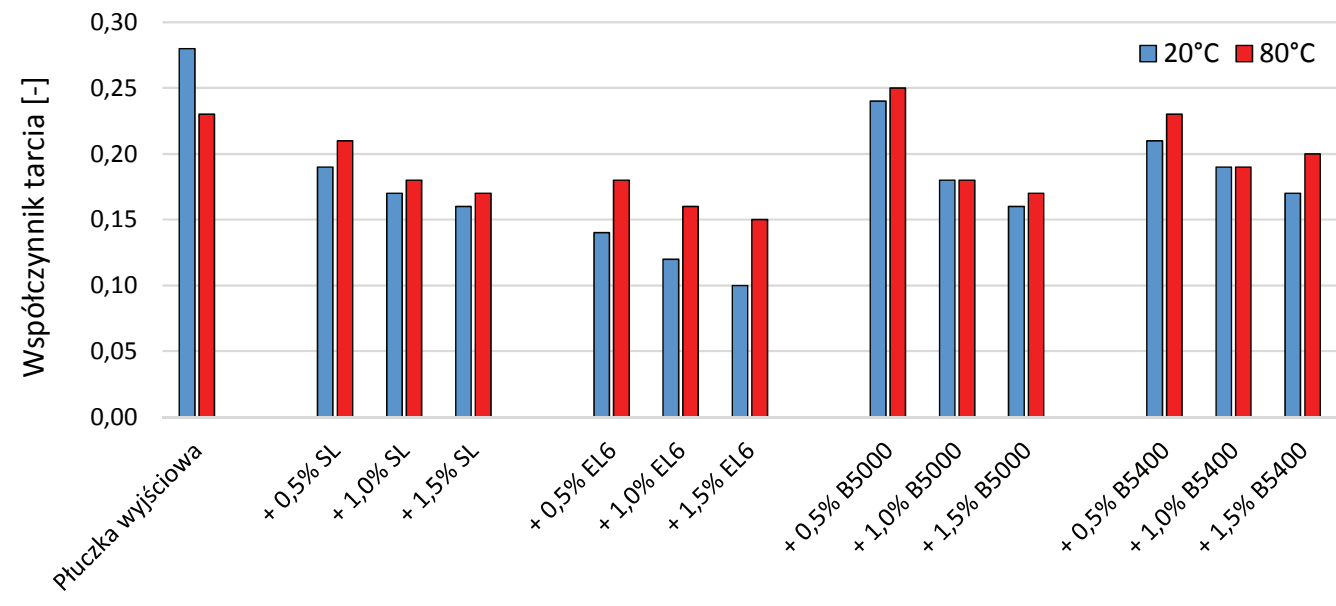

Rys. 3. Współczynnik tarcia na kontakcie stal-stal w płuczce glikolowo-potasowej przy różnych stężeniach środków smarnych

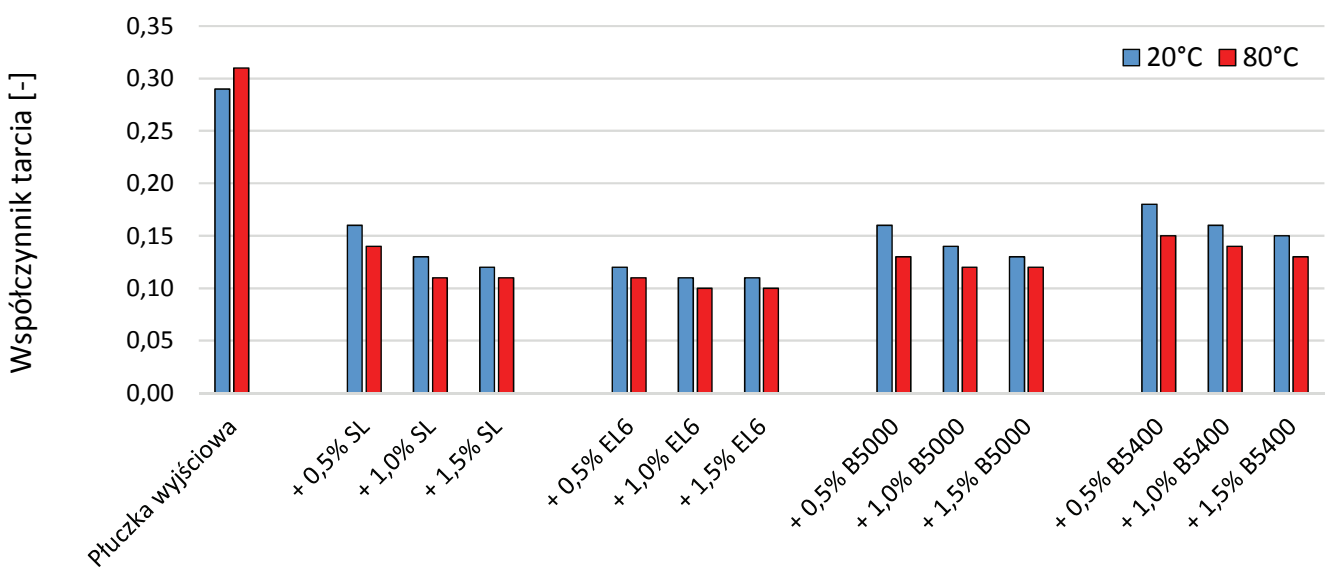

Rys. 4. Współczynnik tarcia na kontakcie stal-piaskowiec w płuczce glikolowo-potasowej przy różnych stężeniach środków smarnych 


\section{Wyniki badania dyspersji łupku mioceńskiego}

Zarówno płuczka polimerowo-potasowa bazowa, jak i jej warianty mające w swoim składzie środki smarne zapewniały niemal całkowity odzysk łupku mioceńskiego - wartość $P_{1}$ zawierała się w przedziale $96 \div 100 \%$. Po oddziaływaniu wody odzysk łupku zawierał się w przedziale $28 \div 52 \%$. Przy stężeniach środka smarnego $\mathrm{w}$ płuczce równych $0,5 \%$ oraz
1,0\% najlepszy rezultat osiągnięto w przypadku EL6 - odpowiednio $36 \%$ i $42 \%$. Wśród płuczek zawierających 1,5\% środka smarnego najbardziej efektywnym działaniem wyróżniła się ta, w której zastosowano środek SL - odzysk zwiercin wyniósł $52 \%$. Uzyskane wyniki przedstawiono w tablicy 3 oraz na rysunku 5 .

Tablica 3. Wartość dyspersji łupku mioceńskiego w płuczce polimerowo-potasowej bazowej oraz zmodyfikowanej dodatkiem środków smarnych

\begin{tabular}{|c|c|c|c|c|c|c|c|c|c|c|c|c|c|}
\cline { 3 - 14 } \multicolumn{1}{c|}{} & \multirow{2}{*}{ Bazowa } & \multicolumn{4}{|c|}{ SL } & \multicolumn{4}{c|}{ EL6 } & \multicolumn{3}{c|}{ B5000 } & \multicolumn{3}{c|}{ B5400 } \\
\cline { 3 - 15 } \multicolumn{1}{c|}{} & & $0,5 \%$ & $1,0 \%$ & $1,5 \%$ & $0,5 \%$ & $1,0 \%$ & $1,5 \%$ & $0,5 \%$ & $1,0 \%$ & $1,5 \%$ & $0,5 \%$ & $1,0 \%$ & $1,5 \%$ \\
\hline$P_{1}$ & 96 & 98 & 96 & 100 & 96 & 98 & 100 & 96 & 96 & 96 & 96 & 96 & 98 \\
\hline$P_{2}$ & 30 & 30 & 32 & 52 & 36 & 42 & 48 & 28 & 34 & 38 & 32 & 38 & 42 \\
\hline
\end{tabular}

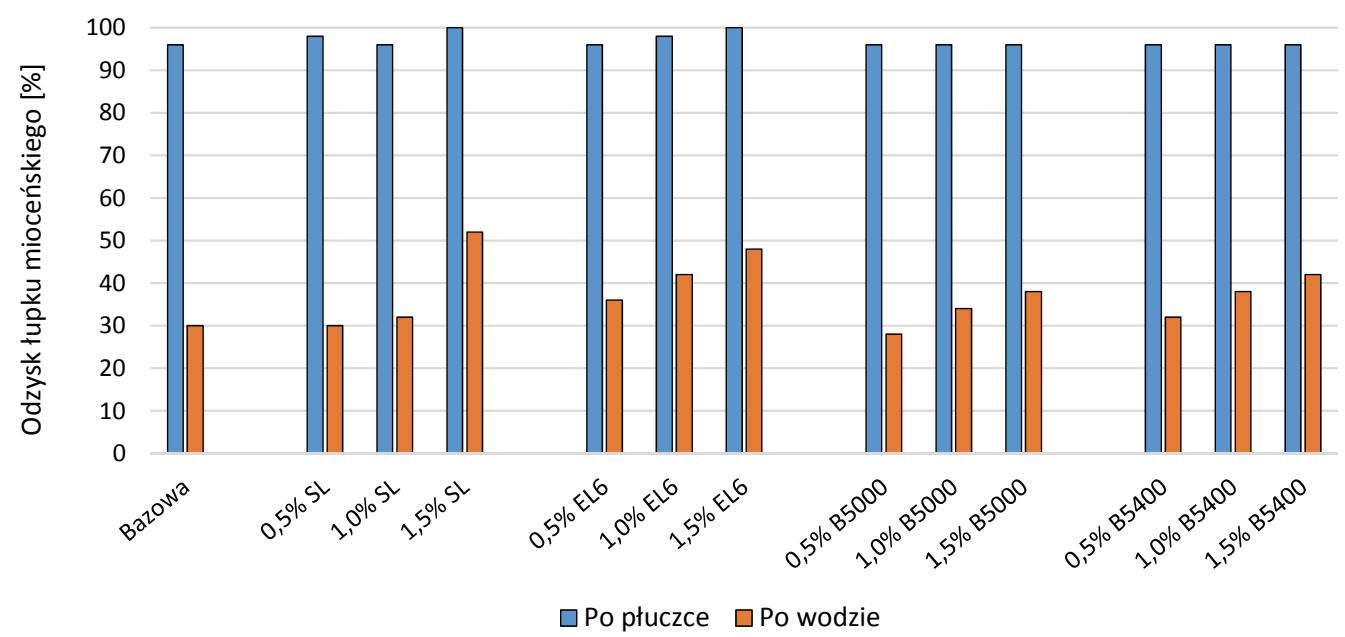

Rys. 5. Dyspersja łupku mioceńskiego w płuczce polimerowo-potasowej

Tablica 4. Wartość dyspersji łupku mioceńskiego w płuczce glikolowo-potasowej bazowej oraz zmodyfikowanej dodatkiem środków smarnych

\begin{tabular}{|c|c|c|c|c|c|c|c|c|c|c|c|c|c|}
\hline & \multirow{2}{*}{ Bazowa } & \multicolumn{3}{|c|}{ SL } & \multicolumn{3}{|c|}{ EL6 } & \multicolumn{3}{|c|}{ B5000 } & \multicolumn{3}{|c|}{ B5400 } \\
\hline & & $0,5 \%$ & $1,0 \%$ & $1,5 \%$ & $0,5 \%$ & $1,0 \%$ & $1,5 \%$ & $0,5 \%$ & $1,0 \%$ & $1,5 \%$ & $0,5 \%$ & $1,0 \%$ & $1,5 \%$ \\
\hline$P_{1}$ & 100 & 98 & 98 & 98 & 98 & 98 & 98 & 100 & 98 & 98 & 98 & 98 & 100 \\
\hline$P_{2}$ & 70 & 70 & 72 & 76 & 68 & 72 & 74 & 68 & 70 & 72 & 72 & 70 & 74 \\
\hline
\end{tabular}

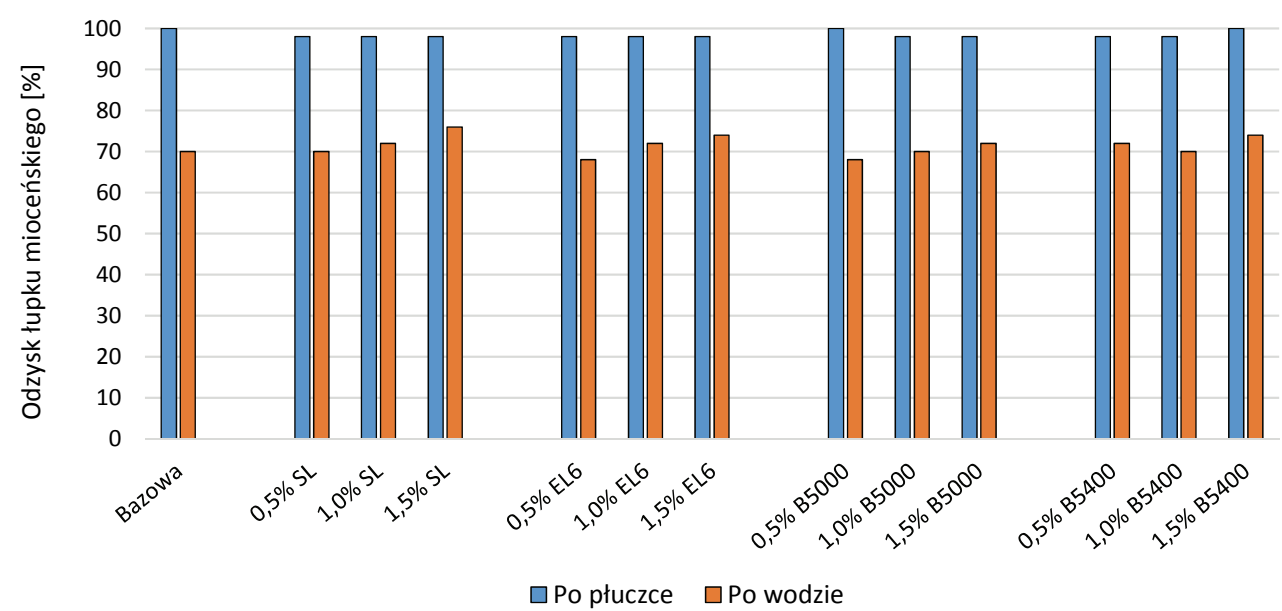

Rys. 6. Dyspersja łupku mioceńskiego w płuczce glikolowo-potasowej 
Podobnie jak podczas badania płuczki polimerowo-potasowej, również płuczka glikolowo-potasowa oraz jej warianty zawierające środki smarne zapewniały bardzo wysoki odzysk łupku $P_{1}-98 \%$ do $100 \%$. Wykazały się one jednak zdecydowanie wyższym stopniem zabezpieczenia zwiercin przed niekorzystnym oddziaływaniem wody - wyniki osiągnęły nawet $76 \%$ po zastosowaniu 1,5\% środka SL. Uzyskane rezultaty zestawiono w tablicy 4 oraz przedstawiono na rysunku 6 .

Przeprowadzone badania wykazały, że zarówno w przypadku płuczki polimerowo-potasowej, jak i glikolowo-potasowej dodatek środków smarnych zwiększa efektywność zabezpieczania skał ilastych przed hydratacją.

\section{Wnioski}

Analiza wyników zrealizowanych badań pozwala przedstawić następujące wnioski:

1. Współczynnik tarcia na kontakcie stal-stal w otoczeniu wyjściowej płuczki polimerowo-potasowej w temperaturze $20^{\circ} \mathrm{C}$ wynosi 0,29 , a w temperaturze $80^{\circ} \mathrm{C}: 0,28$. Wartości współczynnika tarcia na kontakcie stal-piaskowiec są równe odpowiednio 0,45 i 0,34. Badania w środowisku płuczki glikolowo-potasowej wykazały, że posiada ona lepsze właściwości smarne. Wartość współczynnika tarcia na kontakcie stal-stal wynosi $0,28 \mathrm{w}$ temperaturze $20^{\circ} \mathrm{C}$ oraz $0,23 \mathrm{w}$ temperaturze $80^{\circ} \mathrm{C}$. Przy kontakcie stal-piaskowiec jest to $0,29 \mathrm{i} 0,31$.

2. Badane środki smarne o wiele efektywniej obniżają wartość współczynnika tarcia w przypadku piaskowca niż stali. Już koncentracja 0,5\% wystarcza, aby wartość współczynnika tarcia na kontakcie stal-piaskowiec zmniejszyła się o ponad $60 \%$, zarówno $\mathrm{w}$ temperaturze $20^{\circ} \mathrm{C}$, jak i $80^{\circ} \mathrm{C}$.

3. Najwyższą efektywność w poprawie właściwości smarnych płuczek wiertniczych wykazuje środek EL6. W przypadku płuczki polimerowo-potasowej na kontakcie stalstal uzyskano obniżenie wartości współczynnika tarcia o $61 \%$ w temperaturze $20^{\circ} \mathrm{C}$ oraz o $39 \%$ w temperaturze $80^{\circ} \mathrm{C}$ - przy koncentracji środka w płuczce wynoszącej $1,5 \%$. Jeszcze lepsze rezultaty osiągnięte zostały na kontakcie stal-piaskowiec, wartości współczynnika tarcia zostały tam zmniejszone o $73 \%$ i $68 \%$. Analogiczna sytuacja występuje w przypadku pomiarów wykonywanych w otoczeniu płuczki glikolowo-potasowej - również największe obniżenie wartości współczynnika tarcia uzyskano po zmodyfikowaniu składu płuczki za pomocą środka EL6.

4. Najmniej efektywne działanie wykazuje $\mathrm{z}$ kolei środek B5400. W stężeniu 1,5\% w płuczce polimerowo-potasowej na kontakcie stal-stal uzyskano wartości współczynnika tarcia niższe o $29 \%$ w temperaturze $20^{\circ} \mathrm{C}$ oraz o $14 \%$ w temperaturze $80^{\circ} \mathrm{C}$. Pomiary przeprowadzone na piaskowcu dały wyniki niższe o odpowiednio $69 \%$ i $62 \%$.

5. W większości przypadków dodatek środków smarnych powoduje niewielkie obniżenie parametrów reologicznych modyfikowanych płuczek, wzrost filtracji oraz minimalne obniżenie $\mathrm{pH}$. Jedynie przy zastosowaniu 1,5-procentowego stężenia środka SL w płuczce polimerowo-potasowej obserwuje się wyraźny wzrost parametrów reologicznych.

6. Dodatek wszystkich badanych środków smarnych pozwala na uzyskanie wyższego stopnia odzysku łupku mioceńskiego podczas badania dyspersji. Oznacza to, że dodatek środków smarnych ma pozytywny wpływ na właściwości inhibitacyjne płuczek wiertniczych. Najwyższą efektywność w zabezpieczaniu skał przed hydratacją prezentują płuczki zmodyfikowane poprzez dodatek 1,5\% środka SL.

Prosimy cytować jako: Nafta-Gaz 2017, nr 4, s. 257-265, DOI: 10.18668/NG.2017.04.06

Artykuł nadesłano do Redakcji 8.12.2016 r. Zatwierdzono do druku 17.02.2017 r.

Artykuł powstał na podstawie pracy statutowej pt. Analiza skuteczności działania nowych rodzajów środków smarnych w warunkach HPHT - praca INiG - PIB na zlecenie MNiSW; nr zlecenia: 0040/KW/16, nr archiwalny: DK-4100-40/16.

\section{Literatura}

[1] Alford S., Działowski A., Jiang P., Ullmann H.: Research Into Lubricity, Formation Damage Promises to Expand Applications for Silicate Drilling Fluids. SPE 67737, 2001.

[2] Argillier J.-F., Audibert A., Janssen M., Demoulin A.: Performance of a New Biodegradable Ester Based Lubricant for Improving Drilling Operations with Water Based Muds. SPE 37264, 1997.

[3] Blom A., Drummond C., Wanless E.J., Richetti P., Warr G.G.: Surfactant boundary lubricant film modified by an amphi- philic diblock copolymer. Langmuir 2005, vol. 21, no. 7, s. 2779-2788.

[4] Błaż S.: Analiza właściwości technologicznych płuczki inwersyjnej $w$ warunkach HPHT. Nafta-Gaz 2016, nr 6, s. 403-412, DOI: 10.18668/NG.2016.06.03.

[5] Coefficients Of Friction. Strona internetowa Roya Beardmore'a; www.roymech.co.uk/Useful Tables/Tribology/co of frict. htm (dostęp: wrzesień 2016).

[6] Dong X., Wang L., Yang X., Lin Y., Xue Y.: Effect of ester 
based lubricant SMJH-1 on the lubricity properties of water based drilling fluid. Journal of Petroleum Science and Engineering 2015, vol. 135, s. 161-167.

[7] Dubiel S., Al-Ameri M.: Moment obrotowy i sity osiowe dziatajace na przewód podczas wiercenia otworów kierunkowych z poziomym odcinkiem $-w$ świetle rozważań teoretycznych. Wiertnictwo, Nafta, Gaz 1999, t. 16, s. 31-41.

[8] Erhan S.Z., Sharma B.K., Liu Z., Adhvaryu A.: Lubricant base stock potential of chemically modified vegetable oils. J. Agric. Food Chem. 2008, vol. 56, no. 19, s. 8919-8925.

[9] Foxenberg W.E., Ali S.A., Long T.P., Vian J.: Field Experience Shows That New Lubricant Reduces Friction and Improves Formation Compatibility and Environmental Impact. SPE 112483, 2008.

[10] Ismail A.R., Aftab A., Ibupoto Z.H., Zolkifile N.: The novel approach for the enhancement of rheological properties of water-based drilling fluids by using multi-walled carbon nanotube, nanosilica and glass beads. Journal of Petroleum Science and Engineering 2016, vol. 139, s. 264-275.

[11] Kania D., Yunus R., Omar R., Rashid S.A., Jan B.M.: A review of biolubricants in drilling fluids: Recent research, performance, and applications. Journal of Petroleum Science and Engineering 2015, vol. 135, s. 177-184.

[12] Knox D., Jiang P.: Drilling further with water-based fluids. Selecting the right lubricant. SPE 92002, 2005.

[13] Livescu S., Craig S.: Increasing Lubricity of Downhole Fluids for Coiled-Tubing Operations. SPE 168298-PA, 2015.

[14] Nowotarski I. i zespół: Dobór środków smarnych i przeciwzatarciowych do otworów kierunkowych. Dokumentacja INiG, 2000.

[15] Polskie Towarzystwo Tribologiczne. Strona internetowa PTT; http://www.tribologia.org (dostęp: wrzesień 2016).
[16] Raczkowski J., Półchłopek T.: Materiały i środki chemiczne do sporzadzania płuczek wiertniczych. Prace IGNiG 1998, nr 95.

[17] Skalle P., Backe K.R., Lyomov S.K., Kilaas L., Dyrli A.D., Sveen J.: Microbeads as Lubricant in Drilling Muds Using a Modified Lubricity Tester. SPE 56562, 1999.

[18] Uliasz M.: Badania laboratoryjne nad doborem środków poprawiających właściwości smarne płuczki wiertniczej krzemianowej. Dokumentacja INiG, Kraków 2008.

[19] Uliasz M.: Opracowanie pluczek wiertniczych o gęstości regulowanej solami organicznymi. Dokumentacja INiG, Kraków 2012.

[20] Uliasz M.: Właściwości smarne pluczki wiertniczej zawierajacej szkło wodne. Nafta-Gaz 2009, nr 2, s. 133-144.

[21] Uliasz M., Zima G., Błaż S.: Płuczka krzemianowo-potasowa i jej zastosowanie w warunkach otworowych. Wiadomości Naftowe i Gazownicze 2008, nr 4.

[22] Uliasz M. i zespół: Nowe aplikacje w zakresie udostępniania i eksploatacji złóż węglowodorów otworami kierunkowymi i poziomymi. Pluczki wiertnicze w technologii wiercenia otworów kierunkowych i poziomych. Dokumentacja INiG, Kraków 2006.

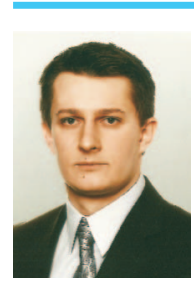

Mgr inż. Bartłomiej JASIŃSKI

Asystent w Zakładzie Technologii Wiercenia. Instytut Nafty i Gazu - Państwowy Instytut Badawczy ul. Lubicz 25 A

31-503 Kraków

E-mail: bartlomiej.jasinski@inig.pl

\section{OFERTA}

\section{ZAKŁAD TECHNOLOGII EKSPLOATACJI PŁYNÓW ZŁOŻOWYCH}

Zakres działania:

- $\quad$ optymalizacja procesów wydobycia i przygotowania do transportu ropy i gazu;

- bioremediacja gruntów, odpadów wiertniczych i eksploatacyjnych zanieczyszczonych substancjami ropopochodnymi;

- rekultywacja terenów skażonych substancjami ropopochodnymi;

- opracowanie technologii oczyszczania ścieków eksploatacyjnych i wód złożowych z zanieczyszczeń ropopochodnych;

- badania i dobór inhibitorów parafinowo-hydratowych oraz deemulgatorów stosowanych w procesach eksploatacji złóż węglowodorów;

- $\quad$ monitorowanie zmian zawartości związków siarki w podziemnych magazynach gazu i opracowanie koncepcji działań zapobiegających powstawaniu siarkowodoru w złożu;

- monitorowanie jakości gazu w sieciach przesyłowych;

- wykonywanie kart katalogowych oraz opracowywanie opinii bezpieczeństwa użytkowania środków chemicznych stosowanych podczas zabiegów intensyfikacyjnych i eksploatacyjnych w warunkach otworowych;

- $\quad$ analizy płynów złożowych, zanieczyszczeń gleby i ścieków, odpadów wiertniczych i eksploatacyjnych.

Kierownik: prof. dr hab. inż. Teresa Steliga Adres: ul. Armii Krajowej 3, 38-400 Krosno

Telefon: 134366029,134368941 w. 5222

Faks: 134367971

E- mail: teresa.steliga@inig.pl

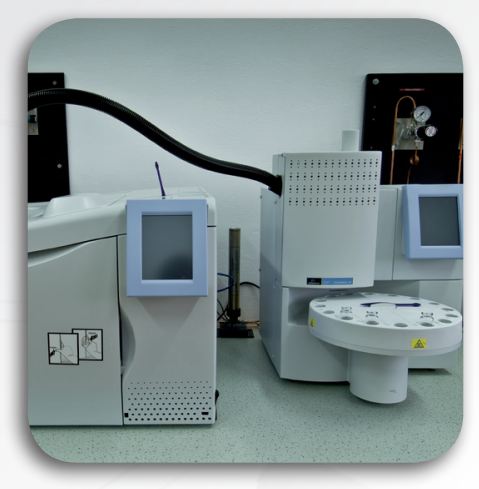

